\title{
INTRODUCTION TO THE SYMPOSIUM ON QUEERING INTERNATIONAL LAW
}

\author{
Gráinne de Búrca*
}

What can the range of ideas and perspectives within queer theory bring to the study and practice of international law? The essays in this symposium address that question in a variety of ways. Some of them focus on issues of gender and sexuality which might be thought of as the core focus of queer theory, such as the coherence of the concept of "gender identity," the limits and potential of human rights law-reform efforts by LGBTIQ+ advocates, and the widening of notions of kinship in the law of reparations. Several other essays range beyond these questions of gender and sexuality to consider the implications of bringing queer perspectives to bear on a broader range of issues within international law and practice, such as the consequences of the consensus rule within the World Trade Organization (WTO), how to organize an academic conference in the field of international law, and the "vision of peace" within international law.

While the essays do not set out to define queerness or to stipulate what questions queer theory should ask of international law, they nevertheless offer a variety of reasons why queer theory might generate interesting inquiries, suggest directions for research and practice, and illuminate issues of power and conformity across the field of international law. Dianne Otto, of Melbourne Law School, describes how the term queer, originally used as an insulting and derogatory term for what was deemed unacceptably different, has been rescued and reclaimed as a lens through which to observe and critique the way certain power relations and inequalities in society are naturalized. For Damian Gonzalez-Salzburg, of Birmingham Law School, queerness refers to a deliberately shifting notion which implies being "at odds with the normal, the legitimate, the dominant . . the normative."1 He suggests that queer theory offers a deconstructive strategy aimed at "de-naturalising traditional conceptions of gender, sexuality, and kinship." 2 Queer commitments, according to Odette Mazel of Melbourne Law School, are "radical and disruptive," intended to expose and problematize "normalized relations of power and privilege in the institutional structures and systems in which we live and operate." Bérénice Schramm of Bahçeşehir University together with her co-authors Manon Beury, Lena Holzer, and Juliana Santos de Carvalho at the Graduate Institute of Geneva, add a further layer by referring to the way queer theory has shed light on international law as a "performative discourse," which has served to reify and legitimate specific representations of the social and political world through legal concepts and categories. ${ }^{4}$ Queer thinking, as Mazel and Otto describe it, aims to destabilize not only such categories, hierarchies, binaries, and understandings of what is "normal," but also the systems — including law_-that enshrine and institutionalize them.

* Florence Ellinwood Allen Professor of Law, NYU School of Law.

${ }^{1}$ Damian Gonzalez-Salzburg, Queering Reparations Under International Law: Damages, Suffering, and (Heteronormative) Kinship, 116 AJIL UnBOUND 5 (2022).

${ }^{2}$ Gonzalez-Salzburg, supra note 1, citing Nikki Sullivan, A Critical Introduction to Queer Theory 81 (2003).

3 Odette Mazel, Queer Jurisprudence: Reparative Practice in International Law, 116 AJIL UnBound 10 (2022).

${ }^{4}$ Bérénice K. Schramm, Manon Beury, Lena Holzer \& Juliana Santos de Carvalho, Doing Queer in the Everyday of Academia: Reflections on Queering a Conference in International Law, 116 AJIL UnBound 16 (2022).

(C) Gráinne de Búrca 2022. Published by Cambridge University Press on behalf of The American Society of International Law. This is 1 an Open Access article, distributed under the terms of the Creative Commons Attribution licence (http://creativecommons.org/ licenses/by/4.0/), which permits unrestricted re-use, distribution, and reproduction in any medium, provided the original work is properly cited. 
Several of the symposium authors point to the way queer theory challenges "heteronormativity," a concept which refers to the way in which heterosexuality is socially and institutionally presented as the normal and coherent organizing principle of society. ${ }^{5}$ As far as international law is concerned, Dianne Otto suggests that many of the conceptual foundations of international law—including its ostensible "civilizing mission" — rely on heteronormativity as a basic organizing principle in a way that tends to normalize inequality, poverty, exploitation, and violence. Queer theory thus shares much in common with other critical theories which have been used to analyze and interrogate international law, including feminist critiques of the militarized international order and Third World approaches (TWAIL) to a deeply unjust political and economic order built on colonial settlement and exploitation. A distinctive emphasis of queer theory, in Otto's words, is in the way it questions "binary orthodoxies" of all kinds (war/peace, male/female, homosexual/heterosexual, etc.), and in how it draws attention to "the harms that human bodies endure during times of peace as well as war." ${ }^{6}$

In her opening essay, Giovanna Gilleri of the University of Milano-Bicocca presents a thought-provoking argument that the category of "gender identity" used in various international law instruments is in fact redundant, on the basis that gender itself is already an identity chosen by the person. ${ }^{7}$ Drawing on elements emerging from international and regional human rights law, she examines the concept of "auto-identification" introduced by the InterAmerican Court of Human Rights (IACtHR), which emphasizes the individual's experience of their gender. Gilleri argues that there are at least three elements that combine to constitute gender: anatomical facts, sociocultural expectations, and the choice of the subject. It is this third element, her essay suggests, which is often overlooked. She compares Jacques Lacan's notion of "sexuation"-effectively the unconscious choice of individuals to identify with a particular gender-with the legal idea of auto-identification introduced by the IACtHR. Gilleri argues that by using the notion of auto-identification, the IACtHR in effect adopted Lacan's concept of sexuation, and acknowledged the implicit choice made by individuals to inhabit a specific gender. She concludes by suggesting that once we recognize that gender itself is a plural notion involving subjective identification and choice, the law should no longer subdivide gender into fragmented categories such as "gender identity," and that the breadth of protection that human rights law gives to individuals on the basis of their gender can accordingly be reconsidered.

Odette Mazel's contribution to the symposium challenges the argument made within queer scholarship that human rights activism and law reform efforts inevitably reinforce heteronormative structures and ideas, supporting governmentality, and becoming a form of depoliticized assimilation. ${ }^{8}$ The essence of this queer critique is that working within the law to demand equal rights necessarily suppresses diversity, reinforcing the conditions that legitimate and maintain heterosexual standards and structural subordination. Mazel however uses ideas from psychoanalytic theory, which distinguish between approaches and practices that are "paranoid" (premised on a kind of opposition between powerlessness/impotence versus agency/omnipotence), as opposed to those that are "reparative" (seeking the "middle ranges of agency" and the empowering and productive capacities of texts and practices). Combining this psychoanalytic call for a reparative approach with Foucault's reflections on how to engage with existing structures of power while simultaneously working to transform them, Mazel argues that some kinds of human rights practice, including recent LGBTIQ+ efforts at legal reform in Australia and elsewhere, can transcend the supposed opposition between cooption/complicity and resistance/opposition, and can themselves be a form of queer jurisprudence. Rather than reinforcing existing structures, she argues that legal reform efforts of

${ }^{5}$ Gonzalez-Salzburg, supra note 1, citing Chrys Ingraham, The Heterosexual Imaginary: Feminist Sociology and the Theories of Gender, 12 Sociological Theory 203, 204 (1994).

${ }^{6}$ Dianne Otto, Queerly Troubling International Law's Vision of "Peace," 116 AJIL Unbound 22 (2022).

7 Giovanna Gilleri, Abandoning Gender "Tdentity," 116 AJIL Unbound 27 (2022).

${ }^{8}$ Mazel, supra note 3. 
these kinds can push boundaries, shift understandings, create a space for difference, and carve new openings within international human rights law.

Damian Gonzalez-Salzburg examines the issue of reparations for unlawful killing in international human rights law. ${ }^{9}$ He draws on queer theory to look at understandings of "kinship" in this field, in examining which family members are deemed worthy of compensation for non-pecuniary suffering when a violation of the right to life has taken place. Pointing to the dominant role of an idealized, traditional, heteronormative, and nuclear family type in international human rights instruments such as the Universal Declaration of Human Rights and the International Covenant on Civil and Political Rights, he argues that they reflect an overarching narrative of a particular and fundamental familial structure "as a pre-social institution, grounded in nature" and requiring recognition and protection by law. Nevertheless, and noting the "living instrument" approach to human rights law adopted by various institutions and courts as well as the culturally evolving notion of the family, he argues that both the European and the Inter-American Courts of Human Rights have, in recognizing a wider range of direct beneficiaries and indirect victims, gradually granted protection to certain forms of kinship that depart from the traditional nuclear family. Echoing some of the concerns of queer scholars that were mentioned by Odette Mazel in her essay-namely, the limits of law reform efforts that merely slightly extend the traditional heteronormative categories to accommodate minor deviations from the norm-Gonzalez-Salzburg questions whether these developments might simply maintain the privileged position of the nuclear family, albeit now "extended to include domestic(ated) same-sex couples." Nevertheless, he argues that the fact that the determination of the relevant kin is a matter to be decided by international law independently of national rules on family and inheritance law, and the fact that regional human rights courts have been validating a wider range of kinship bonds and recognizing emotional ties beyond the traditional nuclear family, opens up "an enticing realm of possibilities" for reevaluating and even overcoming domestic understandings of kinship.

Moving beyond issues of gender and sexuality, the essay by Claerwen O'Hara of Melbourne Law School scrutinizes the consensus rule within WTO decision making from a queer theory perspective. ${ }^{10}$ She points out that queer theorists have criticized the way the use of consensus decision making can marginalize particular voices, and force them "into the closet," because of how "the requirement to 'speak up"' interacts with existing power relations. Unlike a rule of unanimity, which requires the affirmative consent of all parties, a consensus rule assumes the agreement of all unless someone actively speaks up to indicate dissent. Given the vastly unequal power relations between economically dominant states and others, the WTO became a forum in which powerful states used their market size to influence decision making, and in which economically weaker states faced steep political and economic costs if they objected to a proposed decision. O'Hara argues that the use of consensus decision making helped to generate an intolerance of different economic viewpoints and perspectives, and to propagate a discourse in which a commitment to strong trade liberalization and market capitalism was presented as a global consensus to which there was "no rational alternative." From a queer theory perspective, alternative economic ideas such as the New International Economic Order proposed by Global South states, or China's model of state capitalism, are erased by this supposed consensus. O'Hara argues that a singular narrative replaced the plural possibilities of economic ordering, in part contributing to the instability that afflicts the WTO system today. She concludes her essay by supporting Michael Fakhri's proposal to disaggregate trade law across multiple international institutional settings, taking into account the range of very different interests and priorities in contexts such as food security, public health, and labor.

${ }^{9}$ Gonzalez-Salzburg, supra note 1.

${ }^{10}$ Claerwen O' Hara, Consensus and Diversity in the World Trade Organization: A Queer Perspective, 116 AJIL UnBound 32 (2022). 
In their thought-provoking essay, Bérénice K. Schramm, Manon Beury, Lena Holzer, and Juliana Santos de Carvalho describe their efforts to organize a weeklong event on queer methods in international legal scholarship at the Graduate Institute in Geneva. The authors argue that despite the welcome perspectives brought to international law by critical theory and queer theory, these perspectives have not in practice resulted in much real challenge or change to the structures and workings of the university, as the site at which international law is theorized and taught. The authors describe the efforts they engaged in to co-design their workshop in an open, participatory and pluralist way to allow in multiple voices and to upend some of the hierarchical, gendered and racialized everyday practices that often characterize academic conferences. In their words, they sought to create a "site of collective contestation" of the normal practices in legal academia, to foster creativity and learning, to allow for communal projects and to avoid the individualization and isolation of researchers in competitive and "neoliberal academic spaces." This included not only a different way of preparing collectively for the event, but also focusing on issues such as childcare, scheduling, seating arrangements (e.g., in circles to facilitate discussion rather than at a distance), providing spaces for activities such as art pieces, performances, and manifestos, and introducing playful virtual formats and digital platforms. They describe various dilemmas they faced in creating their "everyday utopia in international law," including their awareness of the need to avoid "too much queering" lest this create other forms of discomfort or exclude those who have learned to adhere to the conventional expectations and formats. They conclude their essay by drawing on the work of la paperson ( $K$. Wayne Yang) who has written about the possibility of a "third university" emerging from within the first university ("which accumulates through dispossession") and the second university ("which liberates through liberalism"). The third university, which the authors of this essay hope to help construct, engages in more radical critique and helps in the process of decolonizing the first and second universities. ${ }^{11}$

In the final and most broad-ranging of the contributions to this symposium, Dianne Otto presents a critique of the vision of peace within international law, drawing on queer perspectives to challenge some foundational concepts. ${ }^{12}$ She argues that international law's vision is a top-down one of "bare peace," shaped by the interests of the permanent five members of the UN Security Council, a peace that is understood to be dependent on military power and on a militarized world order, and in which most lives are treated as expendable in the interests of state security as an overriding priority. Otto suggests that this notion of peace relies on heteronormative legal rhetoric, promoting militarism as a manly pursuit and sidelining humanitarian concerns, as well as normalizing existing hierarchies of power and value. Queer theory, she argues, can unsettle how peace is understood and practiced in international law, by "dreaming of a world and its laws devoted to sustaining and enriching life in all its forms," by enabling dominant power relations to be challenged bottom-up, and by replacing the primacy of nationalism with other forms of human kinship. A queer vision of peace, in Otto's view, would be a process of continual nonviolent striving to resist all forms of domination and hierarchy, with a view to ensuring collective well-being.

The title of this introduction asks what queer theory can bring to international law. The essays in the symposium provide a compelling answer not only by explaining the commitments and suppositions of queer theory and the ways in which they are likely to challenge and disrupt existing categories, concepts, and practices of international law, but also by illustrating what queer perspectives can bring to light in particular issue areas-including but not confined to issues of gender and sexuality. At a time when questions of racial, gender, economic, and other kinds of justice have erupted onto national and global agendas, a reminder of the existence of a rich body of critical scholarship focused on probing and challenging existing hierarchies and orthodoxies can help to sharpen the intellectual and analytical tools available to expose and address injustice across the fields of international law and practice.

11 LA PAPERson, A Third University Is Possible (2017).

12 Otto, supra note 6. 